\title{
PEMBERDAYAAN MASYARAKAT MELALUI PENGOLAHAN LIMBAH RUMAH TANGGA MENJADI PUPUK KOMPOS
}

\section{COMMUNITY EMPOWERMENT THROUGH THE PROCESSING OF HOUSEHOLD WASTE INTO COMPOST FERTILIZER}

\author{
Benidzar M Andrie*, Muhammad Nurdin Yusuf, Rian Kurnia \\ Fakultas Pertanian Universitas Galuh \\ Jl. R.E. Martadinata No. 150 Ciamis 46275 \\ *Email: beni.andrie1992@gmail.com \\ (Diterima 06-08-2021; Disetujui 23-08-2021)
}

\begin{abstract}
ABSTRAK
Sampah rumah tangga merupakan sampah yang berasal dari kegiatan-kegiatan sehari-hari dalam rumah tangga. Tujuan dari kegiatan pengabdian ini meningkatkan pemahaman masyarakat mengenai pemanfaatan limbah rumah tangga dan pengolahan limbah rumah tangga yang sering dibuang begitu saja dimanfaatkan supaya mendapat nilai tambah dengan dibuat menjadi pupuk kompos. Sasaran dari kegiatan ini adalah kelompok tani Sandaan di Desa Banjarsari Kecamatan Sukaresik Kabupaten Tasikmalaya. Metode yang digunakan untuk menyampaikan informasi pemahaman masyarakat mengenai pemanfaatan limbah rumah tangga yaitu penyuluhan tatap muka, yang disertai kegiatan memberikan pelatihan cara pengolahan limbah rumah tangga menjadi pupuk kompos. Hasil kegiatan pengabdian ini membuat para anggota kelompok tani Sandaan sadar akan membuat pupuk kompos bisa dibuat dari limbah atau sampah rumah tangga.
\end{abstract}

Kata kunci: Pemberdayaan, Pengolahan Sampah, Kompos

\section{ABSTRACT}

Household waste is garbage that comes from daily activities in the household. The purpose of this community service activity is to increase public understanding of the use of household waste and treatment of household waste which is often thrown away and used so that it can get added value by making it into compost. The target of this activity is a group of hostage farmers in Banjarsari Village, Sukaresik District, Tasikmalaya Regency. The method used to convey information on people's understanding of the use of household waste is face-to-face counseling, accompanied by activities providing training on how to treat household waste into compost. The results of this service activity made the members of the Sandaan farmer group aware that compost could be made from waste or household waste.

Keywords: Empowerment, Waste Processing, Compost

\section{PENDAHULUAN}

Perkembangan ilmu pengetahuan dan teknologi khususnya teknologi informasi pada saat ini sangat mendukung dalam penyediaan informasi lingkungan. Melalui teknologi internet, informasi mengenai permasalahan lingkungan dan penanganannya dapat dilakukan dengan mudah. Kebijakan Otonomi Daerah sebagaimana dirumuskan dalam Undang-Undang Nomor 22 Tahun 1999, menegaskan adanya otoritas pemerintah daerah untuk mengurus dan mengelola berbagai sektor pembangunan dengan inisiatif dan prakarsa kreatif bagi kepentingan dan kesejahteraan rakyat daerah (Agency, Sampah, \& Masyarakat, 2008). 
Tanah mengalami pencemaran apabila ada bahan-bahan asing, baik yang bersifat organik maupun bersifat anorganik yang berada di permukaan tanah yang menyebabkan tanah menjadi rusak dan tidak dapat memberikan daya dukung bagi kehidupan manusia (Wardhana, 2004). Salah satu polutan tanah yaitu pupuk anorganik/sintetik (buatan pabrik). Pupuk anorganik digunakan untuk meningkatkan produksi pertanian. Pupuk anorganik banyak digunakan oleh petani, hal ini dikarenakan lebih efisien dan efektif disbanding dengan pupuk organik. Namun, apabila pupuk anorganik digunakan secara berlebih akan menjadi pencemar tanah.

Salah satu solusi pencemaran tanah yaitu mengolah sampah organik menjadi pupuk organik. Kompos adalah salah satu pupuk organik yang sangat bermanfaat bagi peningkatan produksi pertanian baik kualitas dan kuantitas, mengurangi pencemaran lingkungan dan meningkatkan kualitas lahan secara berkelanjutan (Hiola, 2015). Selain itu, sistem pengomposan memiliki beberapa keuntungan, antara lain: kompos merupakan jenis pupuk yang ekologis ramah lingkungan, bahan yang dipakai tersedia (tidak perlu dibeli) dan dapat sendiri oleh masyarakat secara mudah sehingga membantu perekonomian. Bahan-bahan pembuatan kompos antara lain sampah-sampah organik seperti limbah organik rumah tangga, daun-daun yang jatuh dari pohon, sisa-sisa sayur buah dari pasar dan sebagainya.

Salah satu metode sederhana pembuatan kompos yaitu metode keranjang takakura dengan bantuan Molekul Organisme Lokal (MOL). MOL merupakan mikroorganisme yang dapat mengurai bahan organik menjadi bahan anorganik yang dibutuhkan oleh tumbuhan untuk tumbuh. Pembuatan dengan metode takakura ini cocok untuk skala rumah tangga. Hal ini dikarenakan menggunakan alat dan bahan yang sederhana dan tersedia di rumah. Menurut Tim Move Indonesia (2017), pengomposan cara ini sangat bermanfaat untuk para mahasiswa, bujangan, keluarga kecil, karena bisa ditempatkan di dalam kamar, apartemen, atau di dalam rumah biasa.

Pupuk kompos sering didefinisikan sebagai suatu proses penguraian yang terjadi secara biologis dari senyawa-senyawa organik yang terjadi karena adanya kegiatan mikroorganisme yang bekerja pada suhu tertentu di dalam atau wadah tempat pengomposan berlangsung. Bahan pembuatan pupuk organik yang lebih dikenal dengan kompos, dapat memanfatkan sayuran sisa rumah tangga, daun-daunan, rumput, buah-buahan yg busuk, nasi, dan bahan lain yg bersifat organik. Bahan-bahan tersebut mudah didapat dan setiap hari di sekitar rumah warga (Febrianna et al, 2018; Kasmawan et al, 2018; Nur et al, 2016). Hal itulah yang mendasari pengabdian ini 
membuat alternative pemecahan masalah terhadap hal tersebut untuk membantu lingkungan sekitar yaitu dengan memanfaatkan limbah tersebut dengan menjadikannya sebagai kompos yang menggunakan teknologi yang sederhana dan cara pembuatannya lebih mudah dibuat karena memanfaatkan dari bahan yang mudah didapat.

Berdasarkan identifikasi masalah, rumusan masalahnya yakni:

1. Bagaimanakah caranya meningkatkan pemahaman masyarakat mengenai pemanfaatan limbah rumah tangga?

2. Bagaimanakah cara pengolahan limbah rumah tangga menjadi pupuk kompos?

\section{BAHAN DAN METODE}

Metode yang akan digunakan dalam melaksanakan pengabdian ini yaitu metode instruksional yang diikuti dengan praktek dan pembuatan demplot. Tahapan kegiatan yang akan dilaksanakan meliputi tiga tahapan, yaitu:

1) Penyampaian informasi teknologi (sosialisasi/penyuluhan) kepada anggota kelompok.

2) Pelatihan keterampilan sekaligus pembuatan pupuk kompos.

Bahan dan alat yang dibutuhkan pembuatan pupuk kompos cair antara lain adalah limbah organik rumah tangga, sampah-sampah organik, toples untuk pengomposan dan hasil pengomposan, sendok makan, botol, gula, cairan EM4 dan air. Cara pembuatan alat komposter sebagai wadah pupuk kompos cair adalah sebagai berikut:

1. Dibuat satu lubang di bagian bawah ember/toples, posisi lubang harus lebih rendah sekitar $10 \mathrm{~cm}$ dari alas ember/toples. Lubang ini dipakai untuk pemasangan kran.

2. Ember/toples dilubangi sesuai dengan pipa kran jangan sampai lubang terlalu besar agar tidak terjadi kebocoran

3. Kran dipasang pada lubang yang telah dibuat, kemudian lem dengan lem paralon.

4. Kemudian Pasang Saringan di bagian bawah ember/toples dengan posisi harus di atas kran agar kran tidak tersumbat ampas pupuk kompos.

5. Untuk lebih efektif digunakan 2 ember/toples, kemudian dipasang saringan di antara kedua ember/toples.

6. Alat komposter siap digunakan.

Proses pembuatan larutan pengurai pupuk kompos cair dapat diuraikan sebagai berikut:

a. Gula dan EM4 sebanyak 1 sendok makan dimasukan ke dalam botol air mineral 600 $\mathrm{ml}$. 
b. Isi botol air mineral $600 \mathrm{ml}$ yang sudah berisi gula dan EM4 tersebut dengan air bersih sampai air penuh, lalu kocok botol air mineral $600 \mathrm{ml}$ tersebut sampai ketiga bahan tersebut tercampur sempurna.

\section{Langkah-langkah Kegiatan}

Adapun langkah-langkah dalam pelaksanaan kegiatan pengabdian ini adalah sebagai berikut:

1. Langkah 1

Peserta pengabdian diberikan materi mengenai perbedaan sampah, pemanfaatan limbah rumah tangga dan pentingnya pengolahan sampah untuk nilai tambah.

2. Langkah 2

Peserta diberikan materi dan bimbingan mengolah samapah/limbah rumah tangga menjadi pupuk kompos.

3. Langkah 3

Peserta dan pemateri membuat pupuk kompos dalam skala kecil untuk praktek.

\section{HASIL DAN PEMBAHASAN}

Kecamatan Sukaresik adalah salah satu kecamatan yang berada di Kabupaten Tasikmalaya dengan luas wilayah 1.739,00 ha dan ketinggian rata-rata 500700 meter dari permukaan laut.

a. Batas wilayah

- Sebelah Utara Kecamatan Pagerageung

- Sebelah Timur Kabupaten Ciamis.

- Sebelah Selatan Kecamatan Jamanis

- Sebelah Barat Kecamatan Ciawi

b. Wilayah administrasi

Kecamatan Sukaresik terdiri atas delapan Desa dengan klasifikasi enam desa pedesaan dan dua desa perkotaan.

\section{Jumlah Penduduk}

Menurut BPS Kabupaten Tasikmalaya (2020), Jumlah desa di Kecamatan Sukaresik pada tahun 2019 adalah 8 desa dengan 29 kedusunan, 68 rukun warga (RW), dan 191 rukun tetangga (RT). Jumlah penduduk Desa Banjarsari pada tahun 2019 tercatat ada 4.048 orang, terdiri atas 2.027 orang laki-laki dan 2.028 orang perempuan. 


\section{Penduduk Desa Banjarsari \\ Kecamatan Sukaresik}

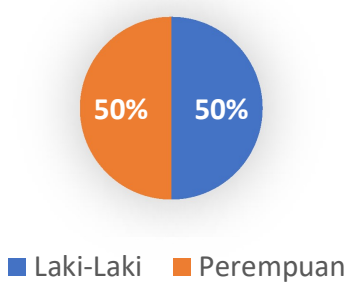

\section{A. Sex Ratio}

Sex Ratio merupakan perbandingan antara jumlah penduduk perempuan dengan penduduk laki-laki. Untuk menghitung Sex Ratio di Desa Sukamantri menggunakan rumus menurut Nurdin (2000) sebagai berikut:

$$
\begin{aligned}
\text { Sex Ratio } & =\frac{\text { Jumlah Penduduk Laki }- \text { laki }(\text { orang })}{\text { Jumlah Penduduk Perempuan }(\text { orang })} \times 100 \\
& =\frac{2027}{2028} \times 100 \\
& =99
\end{aligned}
$$

Nilai sex ratio sebesar 99 menunjukkan, bahwa setiap 99 orang penduduk lakilaki di Sukamantri berbanding dengan 100 orang penduduk perempuan.

\section{B. Keadaaan Kelompok Tani}

Kelompok Tani Sandaan Lingkung Gunung yang berlokasi di Desa Banjarsari Kecamatan Sukaresik Kabupaten Tasikmalaya dibentuk pada bulan Januari tahun 2018. Kelompok Tani Sandaan saat ini beranggotakan 20 orang dengan usahatani komoditas utama yang diusahakan adalah padi. Kelompok Tani Sandaan dipimpin oleh ibu Kokom Komariah, dalam menjalankan organisasi/kelompok yang dipimpinnya, ibu Kokom Komariah dibantu oleh para pengurus yang lain, yaitu sekretaris dan bendahara.

\section{Keadaan Sosial Ekonomi Anggota Kelompok}

Keadaan sosial ekonomi yang dibahas meliputi umur, tingkat pendidikan, tanggungan keluarga, pengalaman berusahatani, dan skala usaha.

\section{a) Umur}

Berdasarkan hasil analisis diketahui bahwa umur para petani di Kelompok Tani Sandaan berkisar 30-55 tahun. Hal tersebut menunjukkan bahwa para petani di Kelompok Wanita Tani Lingkung Gunung berada pada usia produktif. Wirosuhardjo (2004) menyatakan, bahwa kategori usia produktif yaitu antara 15 sampai dengan 64 tahun. 
b) Tingkat Pendidikan

Pendidikan formal merupakan salah satu indikator yang menentukan tinggi rendahnya kualitas sumberdaya manusia. Pada umumnya, semakin tinggi tingkat pendidikan seseorang, maka semakin tinggi pula responnya terhadap inovasi teknologi. Hasil analisis menunjukkan bahwa sebagian besar petani di Kelompok Tani Sandaan yaitu sebanyak 10 orang atau 50\% tamat SLTA, sedangkan sisanya yaitu 5 orang (25\%) tamat SLTP, dan 5 orang (25\%) tamat SD. Hal tersebut menunjukkan, bahwa tingkat pendidikan para petani di Kelompok Tani Sandaan relatif baik, karena di atas rata-rata tingkat pendidikan para petani di Indonesia pada umumnya.

c) Jumlah Tanggungan Keluarga

Jumlah tanggungan keluarga yang dimaksud pada pembahasan ini yaitu jumlah anggota keluarga yang menjadi tanggungan kepala keluarga meliputi suami/istri, anak atau anggota keluarga lain yang menjadi tanggung jawab petani dalam memenuhi kebutuhan hidupnya sehari-hari. Hasil analisis menunjukkan bahwa jumlah tanggungan keluarga para petani di Kelompok Wanita Tani Lingkung Gunung berkisar 2-4 orang. Dari jumlah anggota sebanyak 20 orang, sebagian besar petani $(60 \%)$ mempunyai tanggungan keluarga sebanyak 2 orang. Sedangkan sisanya memiliki jumlah tanggungan keluarga sebanyak 3 dan 4 orang atau masing-masing sebanyak 20\%. Hal tersebut mengindikasikan bahwa seluruh petani di Kelompok Tani Sandaan mendukung terhadap program Keluarga Berencana.

\section{Kegiatan Pengabdian}

Pada dasarnya seluruh bahan organik lambat laun akan lapuk dan terurai dengan sendirinya. Hasil pelapukan bahan organik ini yang umum dikenal masyarakat sebagai kompos. Kompos merupakan salah satu jenis pupuk organik yang dikenal luas di masyarakat. Kompos berasal dari hasil pelapukan dari bahan organik, baik secara sengaja maupun tidak disengaja. Bila didefinisikan secara lengkap, maka kompos adalah sisa-sisa bahan organik yang telah mengalami pelapukan, bentuknya berubah (menjadi seperti tanah), tidak berbau, dan mengandung unsur yang dibutuhkan tanaman. Kompos juga merupakan salah satu jenis pupuk organik yang berasal dari penguraian/dekomposisi bahan organik yg dilakukan oleh mikro-organisme aktif (bakteri/jamur/mikroba). Terdapat beragam manfaat dari penggunaan kompos dalam budi daya tanaman. Penambahan kompos pada media tanam memiliki manfaat dan kelebihan sebagai berikut: 
- Merupakan sumber hara makro dan mikromineral secara lengkap, walaupun dalam jumlah relatif kecil.

- Dalam jangka panjang, kompos dapat memperbaiki pH pada tanah masam.

- Mengandung humus yang sangat dibutuhkan untuk peningkatan hara makro dan mikro pada tanah.

- Memperbaiki struktur tanah yang semula padat menjadi lebih gembur.

- Meningkatkan kapasitas penyerapan air oleh tanah.

- Meningkatkan aktivitas mikroba tanah.

- Menekan pertumbuhan/serangan penyakit tanaman.

Seiring perkembangan ilmu pengetahuan dan beragam penelitian yang telah dilakukan, dewasa ini semakin banyak dikenal berbagai bahan dan metode pembuatan kompos. Sejatinya pembuatan kompos juga harus disesuaikan dengan tujuan pembuatan kompos, sehingga bahan dan manfaat kompos akan sesuai dengan yang diharapkan. Salah satu bahan yang sangat potensial untuk diolah menjadi kompos adalah sampah organik rumah tangga. Pengolahan sampah rumah tangga menjadi kompos memiliki manfaat ganda, yaitu mengatasi masalah sampah rumah tangga, sekaligus mendapatkan pupuk organik yang sangat bermutu. Syarat pertama dan utama dalam pengolahan sampah rumah tangga menjadi kompos adalah pemilahan sampah. Sampah rumah tangga harus selalu dipilah menjadi sampah organik dan anorganik. Hanya sampah organik yang dapat diolah menjadi kompos.

Cara pembuatan kompos dari sampah rumah tangga sangat mudah dan sederhana. Alat dan bahan yang diperlukan cukup murah dan mudah diperoleh. Alat dan bahan yang diperlukan adalah:

(1) Bahan

- Sampah organik (sisa sayuran, nasi, sisa buah-buahan, dan seluruh sampah yang berasal dari bahan organik/bahan alami) .

- Serbuk gergaji / tanah / pupuk kandang

- Aktivator yaitu zat yang akan mengaktifkan kerja organisme pengurai sehingga akan mempercepat proses pembusukan dan penguraian bahan organik. Terdapat banyak jenis aktivator yang beredar di pasaran. Yang umum digunakan salah satunya adalah EM4.

- Air

(2) Alat

- Alat pemotong/pencacah misalnya pisau. 
- Tempat menampung sampah, dapat menggunakan ember bekas cat dan wadah bekas lainnya.

- Alat pengaduk

- Ember/wadah untuk melarutkan aktivator.

Cara membuat kompos dengan memanfaatkan sampah rumah tangga adalah sebagai berikut:

1. Sampah organik rumah tangga hingga dicacah berukuran kecil (semakin kecil, semakin cepat pengomposan berlangsung).

2. Ditambahkan kompos jadi/tanah/pupuk kandang/serbuk gergaji sebagai inokulan.

3. Aktivator dilarutkan dengan air. Larutan aktivator/starter kompos (contoh: EM4) dituangkan ke bahan kompos, kemudian diaduk rata.

4. Larutan aktivator ditambahkan lagi bila campuran terlalu kering.

5. Dimasukkan dalam wadah pengomposan.

6. Ditutup rapat.

7. Diaduk seminggu sekali agar aerasi (aliran udara) dalam wadah berlangsung baik.

8. Selama proses pengomposan, suhu dalam wadah akan naik tanda bahwa mikroorganisme sedang bekerja).

9. Memasuki minggu 7-8 pengomposan selesai, suhu dalam wadah normal kembali. Kompos yang sudah jadi siap digunakan. Bisa dilakukan pengayakan dan pengemasan untuk skala usaha. Kompos yang baik berwarna cokleat kehitaman, berbau tanah, dan berbutir halus.

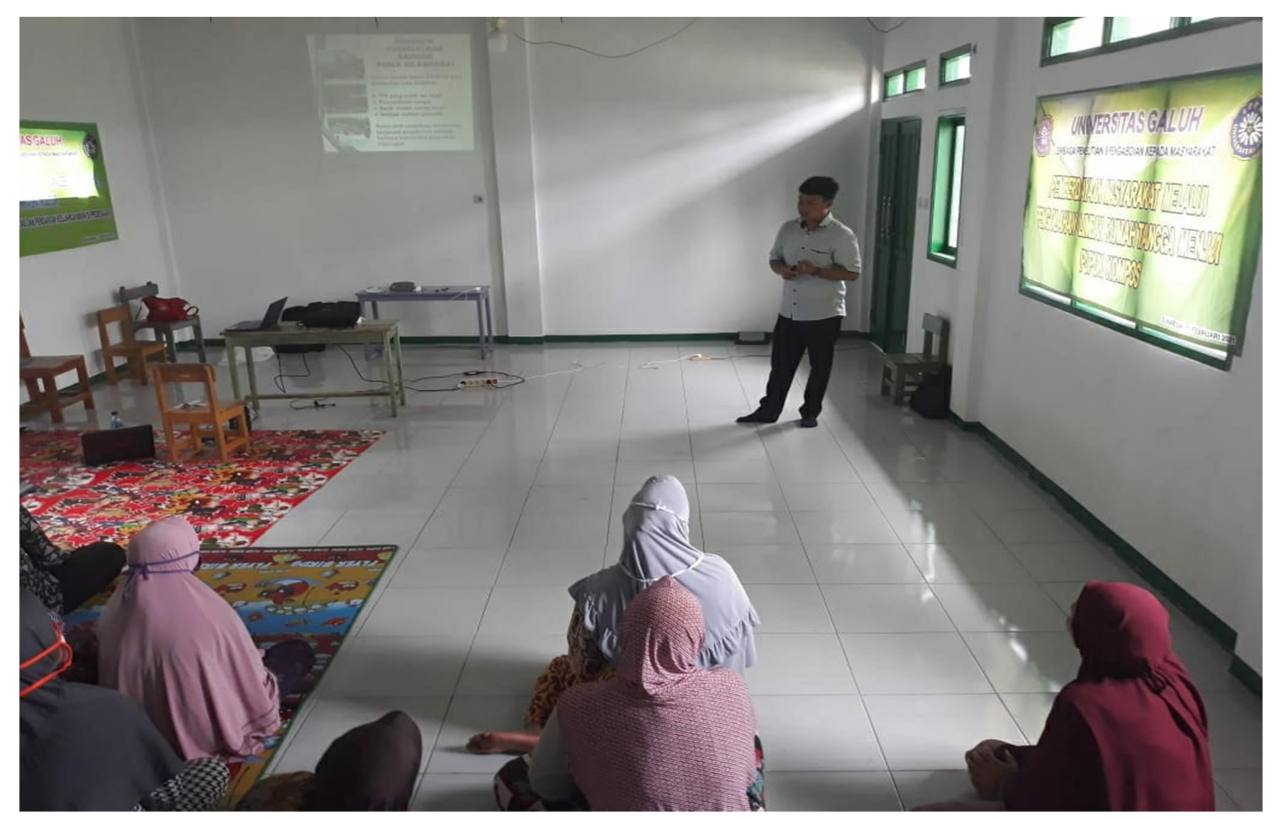

Gambar 1. Pelatihan Pengolahan Limbah Rumah Tangga 


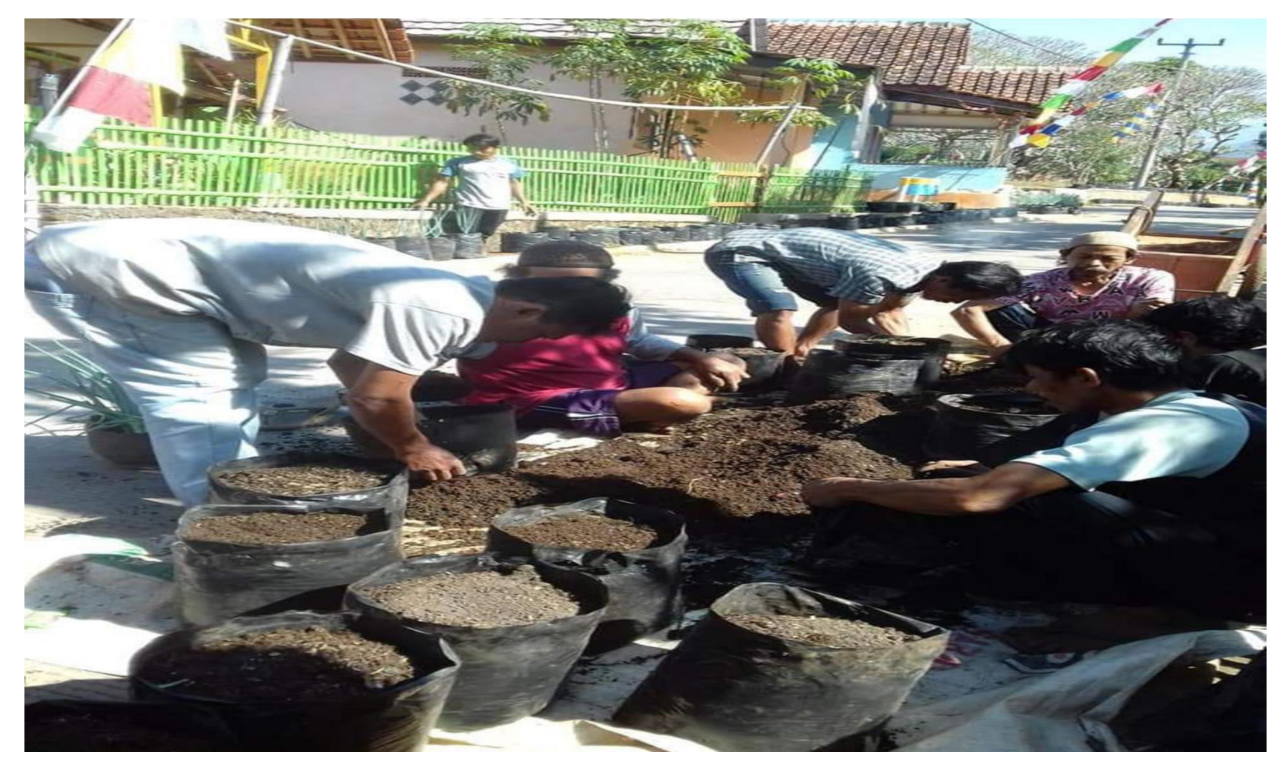

Gambar 2. Pembuatan Pupuk Kompos Secara Sederhana

\section{KESIMPULAN DAN SARAN}

Kelompok Tani Sandaan memahami mengenai pentingnya pemanfaatan limbah rumah tangga sehingga menjadi pupuk kompos. Selain itu, para anggota kelompok tani Sandaan sangat bersemangat dalam pembuatan atau pengolahan membuat pupuk kompos dari limbah rumah tangga.

Saran untuk anggota kelompok tani Sandaan ke depan agar dalam melaksanakan usahatani, khususnya yang berskala kecil, supaya menggunakan pupuk kompos hasil pengolahan limbah rumah tangga.

\section{DAFTAR PUSTAKA}

Agency, I. C., Sampah, P., \& Masyarakat, B. (2008). Pengelolaan sampah rumah tangga berbasis masyarakat - jica, 4-5.

Badan Pusat Statistik Kabupaten Tasikmalaya, 2020. Kecamatan Sukaresik Dalam Angka Tahun 2020. Kabupaten Tasikmalaya : Badan Pusat Statistik.

Febrianna, M., Prijono, S. dan Kusumarini, N. (2018) 'Pemanfaatan Pupuk Organik Cair Untuk Meningkatkan Serapan Nitrogen Serta Pertumbuhan dan Produksi Sawi (Brassica juncea L.) Pada Tanah Berpasir', Jurnal Tanah dan Sumberdaya Lahan, 5(2), 1009-1018.

Rama Hiola Dan Reni Hiola, 2015. TeknologiPembuatan Pupuk Kompos Dari Sampah Rumah Tangga. LaporanAkhir KKS Pengabdian LembagaPengabdian Masyarakat. Jurusan Kesehatan Masyarakat FakultasIlmu-Ilmu Kesehatan Dan Keolahragaan Universitas Negeri Gorontalo.

Tim Move Indonesia. (2007). Ayo membuat kompos Takakura. Mojokerto: Pusat Pendidikan Lingkungan Hidup (PPLH).

Wardhana, W.A. (2004). Dampak pencemaran lingkungan. Jakarta: Andi. 